\title{
Conjoined twins with a single heart with complex disease
}

\author{
Gêmeos unidos com um único coração com doença complexa \\ Gemelos unidos con un solo corazón con enfermedad compleja \\ Julia Simões PABIS ${ }^{1}$ \\ Paulo Victor Zattar RIBEIRO ${ }^{1}$ \\ Milena Luisa SCHULZE ${ }^{\mathbf{1}}$ \\ Júlia de Novaes BENVINUTI ${ }^{2}$ \\ Paulo André RIBEIRO', \\ Francisco Cesar PABIS ${ }^{2}$ \\ ${ }^{1}$ University of Joinville's Region, UNIVILLE 89249-710 Joinville - SC, Brazil \\ ${ }^{2}$ Cor Kids Clinic 89204-250 Joinville - SC, Brazil \\ ${ }^{3}$ Unimed's Joinville Hospital 89204-061 Joinville - SC, Brazil
}

\begin{abstract}
Conjoined twins are a rare presentation with an estimated incidence of 1: 50000 pregnancies. They occur due to a random event, not related to heredity, maternal age or delivery conditions. This article is a case-report of a pair of female thoraco-omphalopagus conjoined twins, who were diagnosed during prenatal period through a morphological ultrasound. After a 24 -week gestation period, the female newborns had a total weight of $1100 \mathrm{~g}$, and were born of a cesarean section. Both fetuses scored 3 in the Apgar scale in the first minute, getting down to a score of 1 in the fifth minute. Soon after birth, the newborns were referred to the Intensive Care Unit, where supportive measures were taken and transthoracic Doppler echocardiography was performed for diagnostic confirmation. The echocardiogram showed that there was only one heart for both newborns with a complex heart disease. In $75 \%$ of the cases of thoraco-omphalopagus conjoined twins, structural heart disfigurements are found in at least one of the fetuses. Besides, in approximately 80-90\% of the cases, the cardiac abnormalities in the heart junction are far too complex, making it impossible to surgically separate the fetuses. This way, a structural and functional analysis of the heart is considerably more efficient post-birth, and it's shown to be more accurately done through an echocardiography. This reveals that cardiac changes are a crucial factor in the fetal and postnatal evaluations of conjoined twins. Such procedures are a way of providing adequate medical recommendations, which may always be honest and based on scientific evidence.
\end{abstract}

Descriptors: Diseases in Twins; Twins, Conjoined; Heart Diseases.

\section{Resumo}

Os gêmeos unidos são uma apresentação rara, com incidência estimada em 1: 50000 gestações. Eles ocorrem devido a um evento aleatório, não relacionado à hereditariedade, idade materna ou condições de parto. Este artigo é um relato de caso de um par de gêmeos unidos toracoonfalópagos do sexo feminino, diagnosticados durante o período pré-natal por meio de ultrassonografia morfológica. Após um período de 24 semanas de gestação, as recém-nascidas do sexo feminino tinham um peso total de $1100 \mathrm{~g}$ e nasceram de uma cesariana. Ambos os fetos marcaram 3 na escala de Apgar no primeiro minuto, chegando a 1 no quinto minuto. Logo após o nascimento, os recém-nascidos foram encaminhados para a Unidade de Terapia Intensiva, onde foram tomadas medidas de apoio e a ecocardiografia transtorácica com Doppler foi realizada para confirmação diagnóstica. $\mathrm{O}$ ecocardiograma mostrou que havia apenas um coração para os dois recém-nascidos, com uma doença cardíaca complexa. Em 75\% dos casos de gêmeos unidos toraco-onfalópágos, alterações cardíacas estruturais são encontradas em pelo menos um dos fetos. Além disso, em aproximadamente $80-90 \%$ dos casos, as anormalidades cardíacas na junção cardíaca são complexas, impossibilitando a separação cirúrgica dos fetos. Dessa forma, uma análise estrutural e funcional do coração é consideravelmente mais eficiente após o nascimento e é demonstrada com mais precisão por meio de uma ecocardiografia. Isso revela que as alterações cardíacas são um fator crucial nas avaliações fetais e pós-natais de gêmeos unidos. Tais procedimentos são uma maneira de fornecer recomendações médicas adequadas, por serem autênticas e baseadas em evidências científicas.

Descritores: Doenças em Gêmeos; Gêmeos Unidos; Cardiopatias.

\section{Resumen}

Los gemelos unidos son una presentación rara, con una incidencia estimada de 1: 50,000 embarazos. Se producen debido a un evento aleatorio, no relacionado con la herencia, la maternidad y las condiciones de maternidad o parto. Este artículo es un caso clínico de un par de géneros toracoonfalopagos femeninos diagnosticados durante el período prenatal mediante ecografía morfológica. Después del período de gestación de 24 semanas, como recién nacidas tenían un peso total de 1100g nacieron por cesárea. Ambos fetos obtuvieron 3 en la escala de Apgar en el primer minuto, alcanzando 1 en el quinto minuto. Poco después del nacimiento, los recién nacidos fueron remitidos a la Unidad de Cuidados Intensivos, donde se tomaron medidas de apoyo y se realizó una ecocardiografía transtorácica con Doppler para confirmación diagnóstica. El ecocardiograma mostró que solo había un corazón para los dos recién nacidos, con enfermedad cardíaca compleja. En el 75\% de los casos de gemelos toracoonfalopagos, se encuentran anomalías cardíacas estructurales en al menos uno de los fetos. Además, en aproximadamente el 80-90\% de los casos, como anomalías cardíacas en el corazón cardíaco completo, impiden una separación quirúrgica en los fetos. De esta manera, un análisis estructural y funcional del corazón es considerablemente más eficiente después del nacimiento y se demuestra con mayor precisión mediante ecocardiografía. Esto revela que los cambios cardíacos son un factor crucial en las evaluaciones fetales y postnatales de los gemelos siameses. Dichos procedimientos son una forma de proporcionar recomendaciones médicas adecuadas, ya que son auténticos y se basan en evidencia científica.

Descriptores: Enfermedades en Gemelos; Gemelos Siameses; Cardiopatías.

\section{INTRODUCTION}

Conjoined twins are a rare presentation with an estimated incidence of 1: 50000 pregnancies, although the incidence of live births is 1:25000 with female predominance $(3: 1)^{1,2}$.

They occur due to a random event, not related to heredity, maternal age or delivery conditions $^{3}$. The cases may be classified into eight different types, each one corresponding to the junction's specific anatomical location ${ }^{3}$ and according to the terminology proposed by Spencer et al. ${ }^{4}$. This report refers to a case of single-heart thoraco-omphalopagus conjoined twins, who carried a complex heart disease which was incompatible with the fetuses' lives.

\section{CLINICAL CASE}

Through a morphological ultrasound, a pair of female conjoined twins was diagnosed as the thoraco-omphalopagus type at their prenatal period. Besides the junction, this had already been identified 
as shown in Figure 1. The diagnosis indicated a severe congenital heart disease which was incompatible with the fetuses' lives and, although they did not have other alterations, it was decided to interrupt the pregnancy.

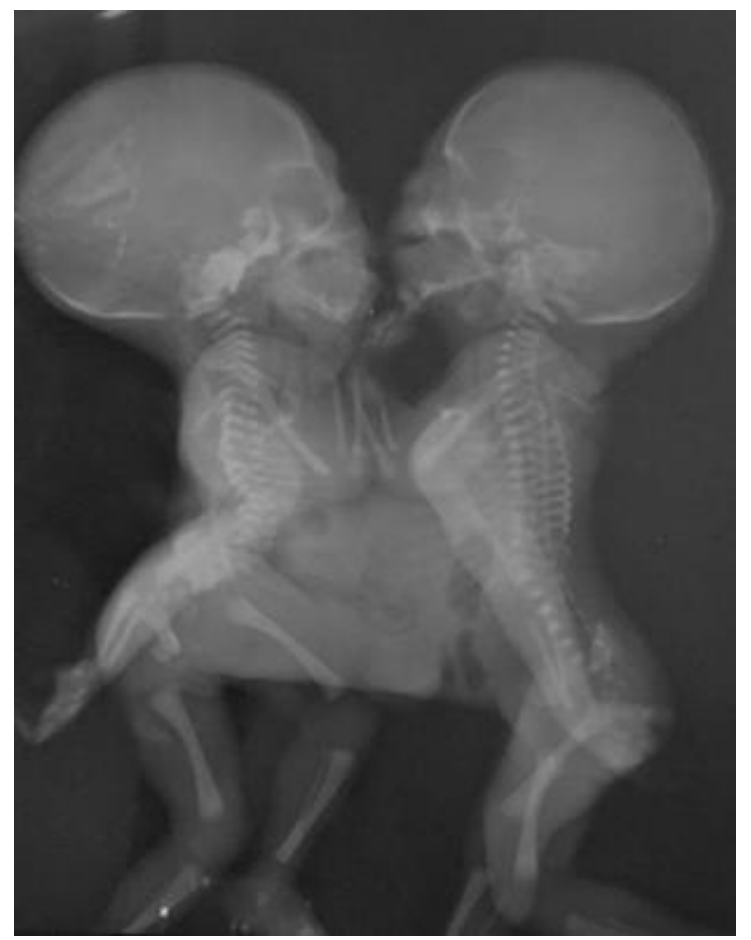

Figure 1: RX performed after the birth in intensive care unit

The serologies collected during prenatal showed that the woman carrying the twins was free of toxoplasmosis, HIV, Hepatitis B and syphilis. At the time, the pregnant woman was 34 years old, had blood type $\mathrm{O}+$ and no previous abortions or miscarriages. After a 24-week gestation period, the female newborns had a total weight of $1100 \mathrm{~g}$, and were born of a cesarean section, having the amniotic sac broken in the act. Both fetuses scored 3 in the Apgar scale in the first minute, getting down to a score of 1 in the fifth minute. The first examination showed that the fetuses were hypotonic, hypoactive, with a single umbilical stump and no bleeding. The doctors also identified agonal breathing which evolved into cyanosis and bradycardia. Through a pulmonary auscultation, vesicular murmurs were identified along with fine creptans snores and rales. The doctors were also able to find, through a heart auscultation, rhythmic sounds, bradycardia and presence of murmur in the twins' heart. Soon after birth, the newborns were referred to the Intensive Care Unit, where supportive measures were taken and transthoracic Doppler echocardiography was performed for diagnostic confirmation. The echocardiogram (Figure 2) showed that there was only one heart for both newborns with a complex heart disease (right ventricular chamber hypoplasia, large atrial septal defect, left atrioventricular valve with significant valve insufficiency, single outlet, and, possibly, truncus arteriosus). Their death was confirmed two hours after birth, without the performance of resuscitation maneuvers - a decision taken by the newborns' family.

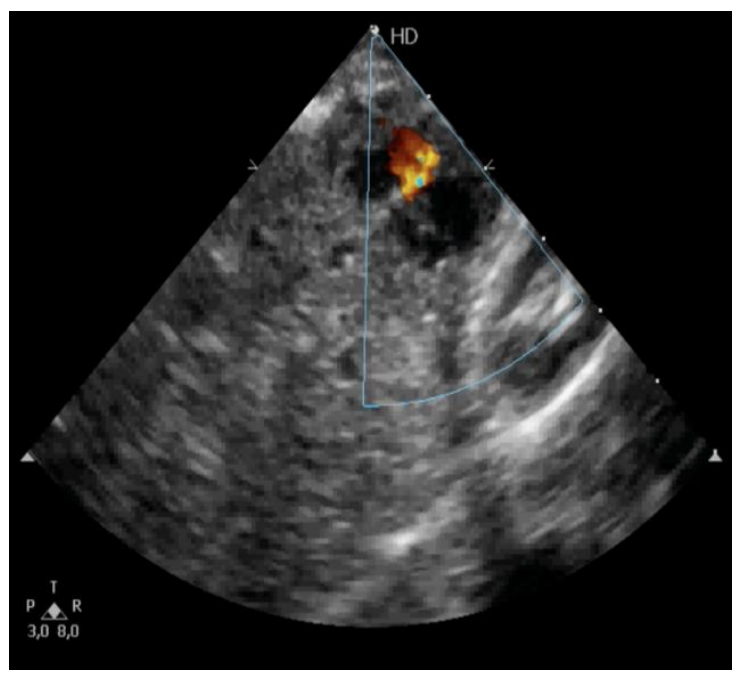

Figure 2: Caption: Four-chamber echocardiogram demonstrating the presence of complex congenital heart disease.

\section{DISCUSSION}

According to the previously developed hypothesis on the division of joint germination, identical twins are formed when a single fertilized egg divides itself into two embryos - a phenomenon which occurs between the 13th and 15th day after fertilization. Thus, a flaw in this process may lead to the formation of conjoined twins. Other theories affirm that this type of formation may come as a result of a secondary fusion of single-ovary embryos that has been previously separated ${ }^{3}$.

In $75 \%$ of the cases of thoraco-omphalopagus twins, structural heart disfigurements are found in at least one of the fetuses ${ }^{4}$. Besides, in approximately $80-90 \%$ of the cases, the cardiac abnormalities in the heart junction are far too complex, making it impossible to surgically separate the fetuses 1 . The twins' cardiac anatomy may be categorized into four fundamental types: 1) Both heart and pericardium are separated, 2) Separated heart and single pericardium, 3) Separate ventricles and single atrium, 4) Single atrium and ventricle ${ }^{5}$.

During the first three months of the pregnancy, the exact details of the heart's interior anatomy are difficult to pinpoint. However, in this gestational phase, it is already possible to identify a cardiac fusion, as well as other major flaws in the heart. Moreover, in the beginning of the second trimester of the pregnancy, it is possible to make a more detailed analysis of the heart's anatomy and the extent of the cardiac fusion. Nonetheless, external cardiac details involving circulatory anastomosis are less likely to be identified before birth ${ }^{6}$.

This way, a structural and functional analysis of the heart is considerably more efficient post-birth, and it's shown to be more accurately done through an echocardiography. As an alternative, the doctors may 
also run a computed tomography which provides contrast for the analysis of the three dimensional planes - a method that is highly recommended for the examination of venous and arterial anatomy ${ }^{7}$.

From the points taken into consideration so far, it is safe to assume that, in the case of any sort of ventricular fusion, surgical procedures become considerably more hazardous and should not be performed1. It is also important to note that some complications (e.g. a defect in one of the twins' heart or a significant arterial perfusion that involves both twins) may be caught up in an extensive ethical debate regarding the surgical separation of the twins, considering that such flaws may lead to the death of one of the fetuses, as it has been the case brought up to the United Kingdom's Supreme Court ${ }^{8}$.

This reveals that cardiac changes are a crucial factor in the fetal and postnatal evaluations of conjoined twins. Such procedures are a way of providing adequate medical recommendations, which may always be honest and based on scientific evidence $^{6}$.

During pregnancy, it is quite usual that the physical and psychological alterations in the woman's body lead to the building of great expectations about the child that she's carrying, which often results in a sort of idealization of the "perfect child". When this idealization is disrupted by the knowledge that said "perfect child" is, instead, a child that needs special care or a child that may not survive due to their special conditions, the baby's parents may have to deal with the strong feelings of frustration, sadness and anguish that come along with the dismantle of the dreams and expectations they had been nurturing. If the child, for some reason, remains alive, the psychological impact of their birth may reverberate in the relationship that the parents are to build with the child - affecting, for example, the quality of the interaction between mother and baby, and in the relationship that other members of the family and other social groups may have with this infant ${ }^{9}$.

The presence of a child diagnosed with a disability or a congenital anomaly in a family implies a great concern over the several special care measurements that are given by the doctors along with the diagnosis because, for the child's parents, who, in most cases, carry the greatest deal of responsibility in this process, there may be consequences regarding their quality of life and bio psychosocial well-being. As far as psychological aspects go, they may be overcome with feelings of depression, sadness, self-devaluation, and guilt as well as show symptoms of disturbance and posttraumatic stress ${ }^{10,11}$.

It is relevant to note, however, that such diagnosis might result in distinct reactions from each of the child's parents. Because the connection between mother and child is inherently stronger, the impact of the birth and presence of a disabled child is often stronger in the mother's perspective, which may also make her adaptation to this situation considerably more difficult. In the father's perspective, the weight of the stigma and the social and financial impacts that the disabled child may bring to the family are usually the most critical factors that end up affecting his life $\mathrm{e}^{10,11}$.

Taking these factors into consideration, it is evident that one must stay aware of the possible repercussions that such situation may bring to the physical, psychological and social aspects of the parents' lives. Such repercussions must be dealt with in an interdisciplinary and multidisciplinary way, in an attempt to provide the family with tools that may minimize the suffering that comes along with this process.

CONCLUSION

From the arguments that have been exposed in this article, it is possible to conclude that cardiac alterations are a crucial factor in the fetal and postnatal evaluation of conjoined twins. Such procedure enables the doctor to give adequate advice to the children's family, and such advice should always be honest and based on scientific evidence in a interdisciplinary and multidisciplinary way, in order to provide solid, comprehensive care to all those involved in the process.

\section{REFERENCES}

1. McMahon CJ, Spencer R. Congenital heart defects in conjoined twins: outcome after surgical separation of thoracopagus. Pediatr Cardiol. 2006;27(1):1-12

2. Rode H, Fieggen AG, Brown RA, Cywes S, Davies MRQ, Hewitson JP et al. Four decades of conjoined twins at Red Cross Children's Hospital-lessons learned. S Afr Med J. 2006; 96(9Pt2):931-40.

3. Barth RA, Filly RA, Goldberg JD, Moore P, Silverman NH. Conjoined twins: prenatal diagnosis and assessment of associated malformations [published correction appears in Radiology 1991 Jan;178(1):287]. Radiology. 1990;177(1):201-7.

4. Spencer R. Anatomic description of conjoined twins: a plea for standardized terminology. J Pediatr Surg. 1996;31(7):941-944.

5. Andrews RE, Yates RW, Sullivan ID. The management of conjoined twins: Cardiology assessment. Semin Pediatr Surg. 2015;24(5):217-20.

6. Andrews RE, McMahon CJ, Yates RW, et al. Echocardiographic assessment of conjoined twins. Heart. 2006;92(3):382-87.

7. Lopes LM, Brizot ML, Schultz R, Liao AW, Krebs VLJ, Francisco RPV et al. Twenty-five years of fetal echocardiography in conjoined 
twins: lessons learned. J Am Soc Echocardiogr. 2013;26(5):530-538.

8. Brooks R. Ian McEwan attacks church over right to die. Sunday may 18 2014. The Sunday Times https://www.thetimes.co.uk/article/mcewanattacks-church-over-right-to-die-gq8nwtbhqjb.

9. Sih DA, Bimerew M, Modeste RRM. Coping strategies of mothers with preterm babies admitted in a public hospital in Cape Town. Curationis. 2019;42(1):e1-8.

10. Albuquerque S, Pereira M, Fonseca A, Canavarro MC. Impacto familiar e ajustamento de pais de crianças com diagnóstico de anomalia congênita: influência dos determinantes da criança. Rev psiquiatr clín. 2012;39(4):136-41.

11. Pereira PK, Lima LA, Legay LF, Santos JFC, Lovisi GM. Congenital malformation of the baby and risk of maternal mental disorders during the pregnancy-puerperal period: a systematic review. Cad Saúde Colet (Rio de Janeiro). 2011;19(1):2-10
CONFLICTS OF INTERESTS

The authors declare no conflicts of interests.

\section{CORRESPONDING AUTHOR}

\section{Milena Luisa Schulze}

milenaluisa.sch@gmail.com 